\title{
THE CONCEPTUAL OF SECOND TRACK DIPLOMACY IN SEA DEFENSE TO INCREASE REGIONAL COMPREHENSIVE ECONOMIC PARTNERSHIP FOR INDONESIA
}

\author{
Angkasa Dipua*, Nuddin Harahab, Romy Hermawan, Dhiana Puspitawati \\ University of Brawijaya, Malang, Indonesia \\ *E-mail: angkasabrawijaya2020@gmail.com
}

\begin{abstract}
The case of disputes that occurred in the South China Sea region is one of the most complicated regional disputes in the Southeast Asian region. This dispute has involved several countries such as Brunei Darussalam, Philippines, Malaysia, China, Taiwan, Vietnam, and covers several issues related to overlapping territorial claims and recognition of territorial sea boundaries in the region. The shift in power from bipolar to multipolar and increasingly unclear threats arose, moving from traditional to non-traditional directions contributed to the tension in the region. Nevertheless, the peace settlement approach that has been attempted so far has not been able to resolve disputes that have existed since four decades ago. This research aims to develop a Second Track Diplomacy (STRAD) Sea Defense concept which is expected to be able to solve the problem of disputes in this region. If referring to the Multi Track Diplomacy theory, it will be more likely to be achieved if it involves and empowers other potentials at all levels of diplomacy, while the concept of Second Track Diplomacy (STRAD) sea defense developed in this study becomes an increasingly important part in changing the international sea defense and security. The results showed that private organizations, non-governmental organizations, universities, and government are expected to be able to use financial and human resources significantly to implement the Second Track Diplomacy (STRAD) concept that focuses on the formulation of a policy for Southeast Asian region, especially on Sea Defense policy. Based on the research results, using the STRAD concept can increase the value of Regional Comprehensive Economic Partnerships (RCEP) for Indonesia in this region with optimal, effective and efficient conditions.
\end{abstract}

\section{KEY WORDS}

Second track diplomacy, sea defense, regional comprehensive economic partnership.

Disputes between the 6 claimant states, namely China, Vietnam, the Philippines, Malaysia, Brunei Darussalam, and Taiwan that have occurred at this time have opened opportunities for the disruption of security stability in the region. In addition to the claimant state, South China Sea (LCS) conflicts also involve the interests of extra-regional countries such as the United States, Russia, India, Japan, and Australia. This is in addition to the fact that LCS is an important Sea Lanes of Communication (SLOC) for merchant ships and tankers heading to the Asia Pacific region, also because it is suspected to have oil and gas content which is very potential to be developed in meeting the world's energy needs in the future. The shift of power from bipolar to multipolar and increasingly unclear threats that arise, moving from traditional towards non-traditional, contributed to the tension in this region. Geopolitical rivalry between the United States and China in the Indo Pacific region will affect the economic interests of all regional countries including Indonesia.

China as the largest petroleum consumer country in the world that is currently unable to meet the needs of domestic economic development to approach double-digit economic growth. Meeting the shortage of needs is supplied from various countries and transported through the LCS. While LCS has a very strategic position for claimant states and extraregional countries, with different interests, ranging from the issue of freedom of navigation, sovereignty, and sovereign right (mainly concerning the management of fisheries and oil and gas), to the problem of the struggle for influence in the region. So for China, LCS is a vital area of interest. 
The escalation of LCS disputes in recent years has intensified, marked by the expulsion of oil exploration vessels, termination of Vietnamese seismic survey vessels by Chinese fishing vessels, deterrence of Filipino warships holding Chinese fishing vessels in Scarborough Shoal waters, Huangyan Island (Robinson, 2010). State borders are physical borders of a state that express sovereignty and sovereign rights in the form of national power in general, and legal power in particular, better known as National jurisdiction. Through borders, countries interact both directly and indirectly with other countries that can have positive and negative effects depending on the ability of the country's interaction. Therefore, state borders have two important functions, namely as boundaries and frontier states (Mapendere, 2016). Regional sovereignty including land, sea, and air areas can be ensured that the management of border areas is very important and strategic. The management of border areas in the context of border area security (frontier) must be implemented in the form of the continued presence of the state defense and security forces to guarantee the sovereignty of the state and the sovereign rights of the state.

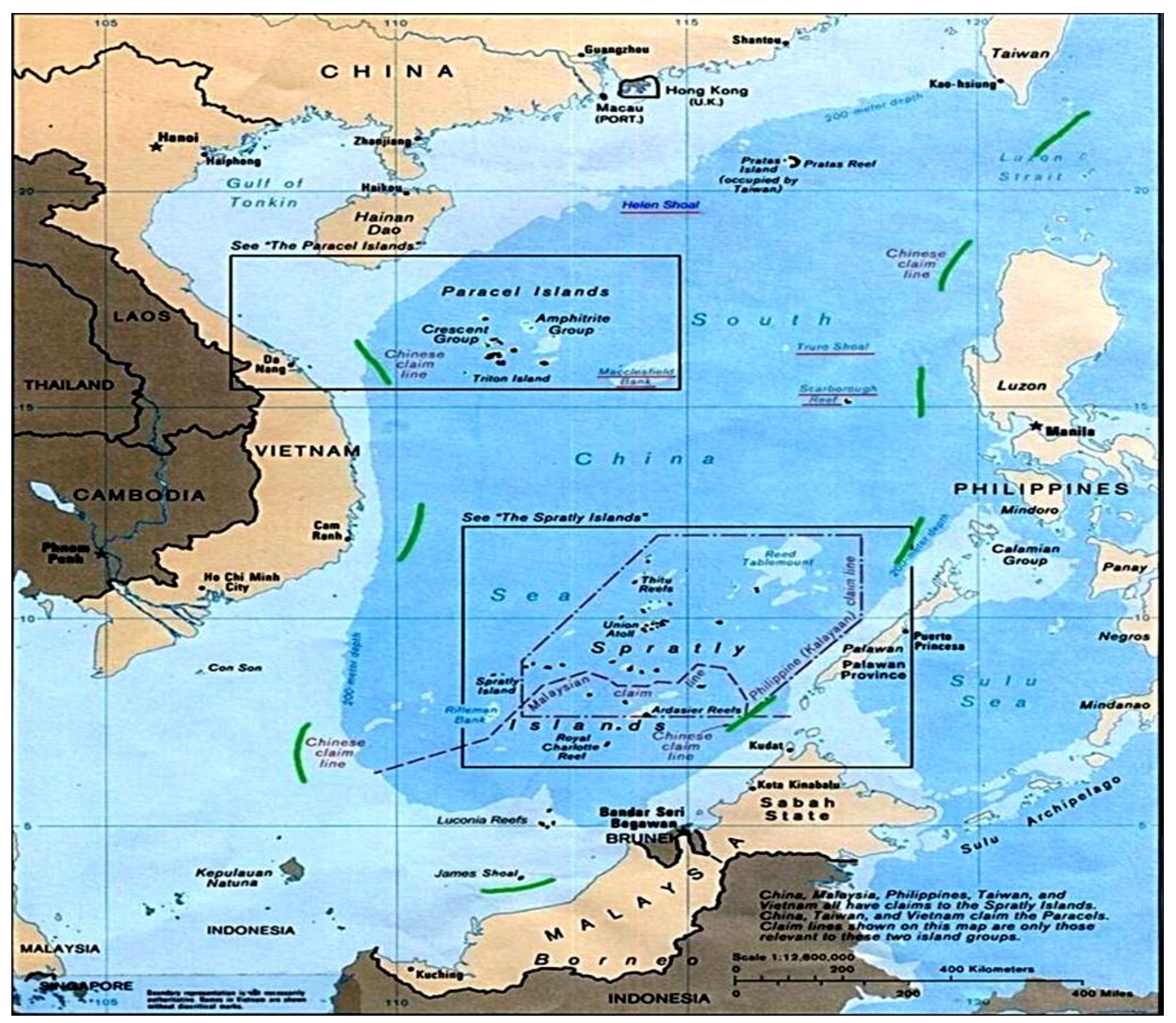

Figure 1 - Nine-Dash Line of China (Source: Ikeshima, 2013)

Research by Taisaku Ikeshima (2013) with the research title "China's Dashed Line in the South China Sea: Legal Limits and Future Prospects". Research using the methodology of observing case studies Variables: According to international law, according to the historical claims of China and according to traditional waters. The results of the study show that: A practical and comprehensive approach, for the South China Sea dispute problem, will be more useful than the application and interpretation of strict laws.

Indonesia does not have a maritime dispute with China and other claimant states, but has an interest in protecting and securing sovereign rights in ZEEI following UNCLOS 82, mainly related to the publication of the Chinese version of the nine-dotted line / nine-dashed 
line in May 2009, as illustrated Figure 1. covers the EEZ region in the Natuna Sea for 60 miles. The publication of the unilateral map by the Chinese state has triggered territorial water disputes (Rustandi, 2015). Disputes and conflicts between countries that intersect in the South China Sea need real efforts in peaceful and effective resolution. Diplomacy has been carried out bilaterally or multilaterally, from each government and foreign ministry. But conflicts continue to occur and distrust persists among these countries so that sometimes there are still hostile attitudes and cause violence on the ground. While official diplomatic communication is a clear way for opponents to speak, while informal policy discourse or second track diplomacy, has become an increasingly important part of changing the international security landscape. Private organizations, nongovernmental organizations (NGOs), universities, and governments have been able to use significant financial and human resources to carry out the second track dialogue. However, this pathway has played an important role in shaping the views, attitudes, and knowledge of political elites, both civilian and military, and in some cases have begun to influence security policy. As a result, we need to set realistic expectations about what can be achieved with STRAD. This STRAD dialogue can change views about the value of cooperation with other regional actors, even if the attitude towards actors remains generally negative. The dialogue functions as a conditioning process whereby regional actors are confronted with new concepts, adapt them to their context and form policy debates over time. However, assumptions about the strength of second track diplomacy (STRAD) are rarely assessed and systematically analyzed through an empirical analysis (Kim, 2016). Regional security efforts through second track diplomacy especially in the field of maritime defense, which uses the STRAD pathway will produce a policy formulation to increase Regional Comprehensive Economic Partnership (RCEP) for Indonesia.

\section{MATERIALS AND METHODS OF RESEARCH}

Roles and Concepts of Second Track Diplomacy (STRAD). Second track diplomacy was first used by Joseph Montville (1991) who used the term to indicate informal efforts in conflict resolution. He defined the second pathway as follows: Unofficial, informal interaction between members of adversarial groups or nations with the goals of developing strategies, influencing public opinion, and organizing human and material resources in ways that might help resolve the conflict (Montville, J. 1991). The term diplomacy which did not use government channels gained its place in the mid-1960s. At that time, Professor John Burton tried to help resolve disputes between Indonesia, Singapore, and Malaysia by inviting a small team to a workshop in 1965-1966.

The use of STRAD has increased beyond the power-based approach by taking over the role of traditional diplomacy from the state as the main resolution of the conflict. In other words, not only pursuing strategic interests by conducting good discussions through the role of government, which prioritizes fundamental characteristics through a first-track mission, STRAD seeks to include all parties in the conflict. STRAD points to an important part of the practice of sharing thoughts between larger groups of citizens, while the first-track diplomacy tends to limit the focus to issues more narrowly than the role of politicians or military leaders. STRAD tries to make its impact felt as a whole from what it describes as an identity group: that is, communities that share a certain ethnic, regional, national, socio-economic, or other identities (John Conyers, 1991).

The concept of STRAD stems from the belief that conflict can be avoided by building friendly relations and sharing understanding between people. Changes in the way they think, resolve conflicts, and find possible solutions is the goal to bring people together in solving problems. in this way, STRAD can turn conflict into the constructive dialogue between those involved in disputes. "The use of force, the formal and often inflexible method of formal interface among governments that are short of free states" is the definition of First-Track diplomacy. Besides, the first-track practice can easily be interpreted as interference in the internal affairs of the nation freely. In situations such as where the first Track communication 
can be easily damaged or increase the severity, so STRAD can become a working method to continue the dialogue and interaction needed for conflict resolution.

STRAD is a form of resolving non-governmental, informal, and informal conflicts that has the potential to reduce the tendency of prolonged conflict by increasing dialogue and promoting shared interests among warring groups. The importance of pursuing informal communication between conflicting groups is that they can reduce the intensity of conflict before formal talks are held. These informal interventions are easier to implement to deal with intra-state conflicts. Indeed, STRAD should not replace first-track diplomacy, but rather as an additional channel that offers a preliminary segment to carry out dialogue productively. Although STRAD is a relatively new practice, it has been able to record several successes. A classic example is a contribution made by former vice president Yusuf Kalla, who was a negotiator between Indonesia and the Free Aceh Movement.

Management and Public Policy Concept. Associated with the management of conflict in LCS area disputes can be viewed from management theory. In management, the theory is a system to achieve planned goals in which there are functions related to each other. Management is a process that consists of a series of activities, such as planning, organizing, mobilization (actuating) and controlling carried out to determine and achieve the goals set through the utilization of human resources and resources the other.

Understanding Public Policy concept is defined by Scarlett (2009) as whatever is chosen by the government to do or not do. With this definition, the concept of policy according to Dye is a policy made based on the attitude of the government or government decisions regarding issues that occur in the community.

Public policy is an effort chosen by the government to do or not do. proposed by a person, group, or government in a particular environment that provides obstacles and opportunities in overcoming a problem or problem. The policy is an instrument of government, not only in the sense of government that only concerns the state apparatus, but also governance that touches also on the management of public resources. Policies are essentially decisions or choices of actions that directly regulate the management and distribution of natural, financial, and human resources in the public interest, namely the people, population, community, or citizens (Fukunaga, 2014).

Understanding Public Policy The scope of the study of public policy is very broad because it covers various fields and sectors such as economics, politics, social, culture, law, and so on. Besides that, it can be seen from the parked public policies that can be national, regional or locally such as laws, government regulations, presidential regulations, ministerial regulations, regional/provincial government regulations, governor's decisions, district/city regional regulations, and regents/mayors' decisions (Kraft, 2000).

Policy formulation is the earliest step in the overall public policy process. Therefore, what happens in this phase will determine the success or failure of the public policy made in the future. It should also be remembered that good public policy formulation is oriented to implementation and evaluation because often policymakers assume that good public policy formulation is conceptual and loaded with ideal and normative messages, but not down to earth (Schellenberg, 1996).

Research Design Concept. The design used in this study is qualitative. A qualitative design is used because of the formulation of symptoms, information, or information regarding the implementation of LCS conflict resolution. In a qualitative study, it is defined as a process of inquiry to understand social or human problems, based on building complex holistic images, formed with words and reporting detailed views of informants. A qualitative approach in which the main instrument is the researcher himself as the researcher. According to Creswell (2014), problems in qualitative research are temporary, tentative, and will develop or change after the researcher is in the field. Bungin (2011) states that qualitative research starts with thinking inductively, capturing various facts or phenomena through observation, then analyzing and doing theorizing based on what is observed. The inductive process illustrates the efforts of researchers to repeatedly process themes and research databases to build a complete theme (Creswell, 2014). Based on the above concept, the researcher will analyze some written facts about how the second track diplomacy (STRAD) policy 
formulation in the field of maritime defense in enhancing Indonesia's Regional Comprehensive Economic Partnership (RCEP).

Conceptual Framework. The conceptual framework is a formulation or simulation of the theoretical framework or theories that support this research. The conceptual framework in research related to the implementation of STRAD and RCEP policy policies is expected to prevent countries outside the region from engaging in such conflicts as a form of implementing policies in the defense sector with the aim that there is no open conflict in the LCS to support the creation of security in the region, which starts at the current conditions to lead to the expected conditions, by conducting a policy analysis at the implementation level. The conceptual framework of this study can be presented in the form of input, process and output diagrams that describe the research process from obtaining data, processing data to analyzing and evaluating the results/outputs of research data related to LCS conflict resolution.

In the preparation of research designs based on the identification of problems, so that problems can be arranged that cause problem in STRAD. From the existing problems, comprehensive settlement strategies can be drawn up. Furthermore, these strategies can be analyzed under the existing theoretical basis. From the existing strategies, verification and validation tests can be done, so that it can be seen whether the existing strategies are following the objectives to formulate a Second Track Diplomacy (STRAD) policy in the field of marine defense in improving Indonesia's Regional Comprehensive Economic Partnership (RCEP). Furthermore, it can be concluded the results of research and recommendations can be given.

Primary and Secondary Data Sources. Primary data sources obtained by researchers are verbal data or words spoken verbally, gestures or behavior carried out by subjects that can be trusted, namely research subjects or informants who have been concerned with the variables studied or data obtained from respondents directly (Ames, 1993) The primary source of research as interviewees involved relevant officials in the Indonesian Navy and the Ministry of Foreign Affairs. As competent objects and subjects in the field of defense diplomacy both directly and indirectly related to the second track diplomacy (STRAD) policy formulation in the field of sea defense in enhancing Indonesia's Regional Comprehensive Economic Partnership (RCEP).

Secondary data sources that have been generated are data obtained from data collection techniques that support primary data. Secondary sources in this study include various policies related to defense diplomacy, books on defense, scientific journals, and internet sources related to the formulation of second track diplomacy (STRAD) policies in the field of sea defense in enhancing Indonesia's Regional Comprehensive Economic Partnership (RCEP). In this research, observations have been carried out by the authors of the literature study. All supporting secondary data has been examined through graphic documents such as tables, notes, SMS, photos, and others.

Data Collection and Analysis Technique. Data collection techniques have been used by researchers to obtain data in a study. In this study, researchers have used this type of qualitative research in obtaining in-depth, clear, and specific data. Further explained by the collection by researchers obtained from the results of observations, documentation, interviews, and joint / triangulation (Aplianta, 2017). The technique has produced an objective picture of STRAD's policy based on the theory used, secondary data and primary data that have been obtained are based on interviews with competent personnel in the formulation of Second Track Diplomacy (STRAD) policy in the field of marine defense in enhancing Regional Comprehensive Economic Partnership (RCEP) Indonesia.

Qualitative data analysis is an effort that has been done by working with data, organizing data, sorting it out into manageable units, synthesizing it and finding patterns, discovering what's important and what is learned, and deciding what can be told to others (Moleong and Lexy, 2007). The above definition is a guide for researchers in gathering existing data, compiling systematically, and then presenting the results of this study. In the governance science research methodology, the data analysis stage is the process of organizing and sorting data into patterns, categories, and basic units of the description so 
that themes can be found and work hypotheses can be formulated according to those suggested by the data. Data analysis intends to first organize the data by sorting, grouping, coding, and categorizing. The aim is to find work themes and hypotheses which are eventually adopted as substantive theories (Buszynski, 2010). Data analysis has been carried out by conducting in-depth interviews with key informants, namely someone who truly understands and knows the situation about the ins and outs of formulating second track diplomacy (STRAD) policy in the field of marine defense in enhancing Indonesia's Regional Comprehensive Economic Partnership (RCEP). After conducting the interview, the data analysis begins by making a transcript of the interview results, by playing back the recording of the interview results, listening carefully, then writing down the words that are heard following what is in the recording.

The researcher has written the results of the interview into the transcript, then the researcher has read it carefully and then performed data reduction. Researchers have made data reduction by making abstractions, that is, taking and recording useful information under the research context or ignoring unnecessary words so that the essence of the sentence is obtained, in a language that matches the language of the informant. Abstractions that have been made in the form of units which have then been grouped based on the taxonomy of the research domain (Digvijaysinh, 2013). Domain analysis is to obtain a general and overall picture of the object/research or social situation. Researchers have obtained the research domain by conducting grand and mini-tour questions. The domain serves as a foothold for further research. Regarding taxonomic analysis by selecting domains and then spelled out in more detail, so that the internal structure can be known.

Data Validation. In qualitative research, qualitative validity or so-called triangulation does not have the same connotation as validity in quantitative research, nor is it parallel to reliability (which means testing stability and consistency of response) or generalization (which means external validity or research results that can be applied to settings, people, or new samples) in quantitative research) concerning quantitative generalizability and reliability (Creswell, 2010). According to Creswell (2010), eight triangulation or data validity strategies can be used from the easy to the difficult ones, namely:

a. Triangulate different data sources by examining the evidence that comes from these sources and using them to build a coherent justification of themes.

b. Implement member checking to find out the accuracy of the research results. This checking member can be done by bringing back the final report or descriptions or specific themes in front of the participant to check whether the participant feels that the report/description/theme is accurate.

c. Make a rich and concise description of the research results. This description must at least successfully describe the research setting and discuss one element of the participant's experiences.

d. Clarifying the bias that researchers might bring into the study. By reflecting on the possible emergence of bias in research, the researcher will be able to create an open and honest narrative that will be felt by the reader.

e. Present different or negative information that can provide resistance to certain themes. Because real life is created from a variety of perspectives that don't always coalesce, discussing different information is very likely to add credibility to the research results.

f. Utilizing a relatively long time in the field or research location. In this case, researchers are expected to be able to understand more deeply the phenomenon under study and be able to convey in detail about the location and the people who helped build the credibility of the results of the research narrative.

g. Conduct questions and answer with fellow researchers to improve the accuracy of research results. This process requires the researcher to find a partner who can review to discuss qualitative research so that the results of his research can be felt by other people than the researchers themselves.

h. Inviting an auditor (external auditor) to review the entire research project. In contrast to fellow researchers, the auditor is not familiar with the proposed researchers. 
Eight strategies cited from Creswell (2010) as above, the researchers in this study did not use all of them to validate the researchers' data. Researchers use 2 (two) strategies, namely the triangulation strategy (triangulate). The reason for using the triangulation strategy is because first, this strategy is easily affordable for researchers to use. After all, the researcher already has secondary data and comparative informants other than the main informant. Second, practically, this method is more easily practiced to validate the data found by researchers because the objects studied have the same basic tasks and relatively do not have many changes and differences in their applications.

Researchers have triangulated using the following two methods:

a. Triangulation (Significant others). Data validation by triangulation in research through significant others. The results of interviews with the subject are checked by different sources which in this case are significant others as mentioned above. Checking focused on themes that researchers have found based on interview results. In this case, the researcher compared the results of interviews conducted between one informant with other informants to see the suitability of the answers to the questions expressed to the informants. In this case, to obtain data on the second track diplomacy (STRAD) policy formulation in the field of maritime defense in enhancing Indonesia's Regional Comprehensive Economic Partnership (RCEP), the data was collected from interviews with informants of the second track diplomacy (STRAD) policy in the defense sector the sea.

b. Triangulation Method. Method triangulation is done by researchers collecting similar data using different data collection techniques or methods. In this case, the researcher uses document recording, and also through observation.

\section{RESULTS AND DISCUSSION}

Second Track Diplomacy (STRAD). South China Sea (LCS) dispute has become an international political commodity within the framework of power politics for each country that seeks to improve its position of power against rival countries so that these countries try to maintain their hegemony to seize influence in the region so they can continue to exploit the potential that exists along the pacific edge. Changes in the international system that created these new security concepts are behind ASEAN to take part in the resolution of the LCS conflict, in addition to several other ASEAN considerations and interests. With this condition, diplomacy from non-government institutions is called second track diplomacy. ASEAN Second track diplomacy (STRAD) has become an important aspect of cooperation in the Asia Pacific, especially ASEAN. Strad's role is getting bigger when Asean develops a comprehensive security concept in which security concepts include traditional and nontraditional security; including those in the economic, political, and social fields (Kraft, 2010).

The significance of the South China Sea conflict for ASEAN can be briefly described as follows: First, Asean's interest in maintaining the stability of the relations of its member countries, especially those directly involved in the South China Sea conflict (Malaysia, Vietnam, the Philippines, and Brunei Darussalam). Second, the South China Sea is a strategic area. So that this region has the potential to become a military base from countries that will expand its influence in Southeast Asia. Thus, the magnitude of the potential for conflict in the South China Sea region and its influence on the stability of the Southeast Asian region forced ASEAN to think more seriously to guard against all possible security disturbances.

Second Track Diplomacy Phase. Kraft and Edy Kaufman (2000) have developed the second track diplomacy theory. According to Kraft and Edy Kaufman (2000), in the second track diplomacy, there are four lines of diplomacy: diplomacy between state actors, diplomacy conducted by professionals who have close relations with state actors, diplomacy conducted by non-state actors, especially in the context of forming public opinion, and individual diplomacy. 
$\underline{\text { Tracks }} \quad \underline{\text { Actors }} \quad \underline{\text { Leadership Levels }}$

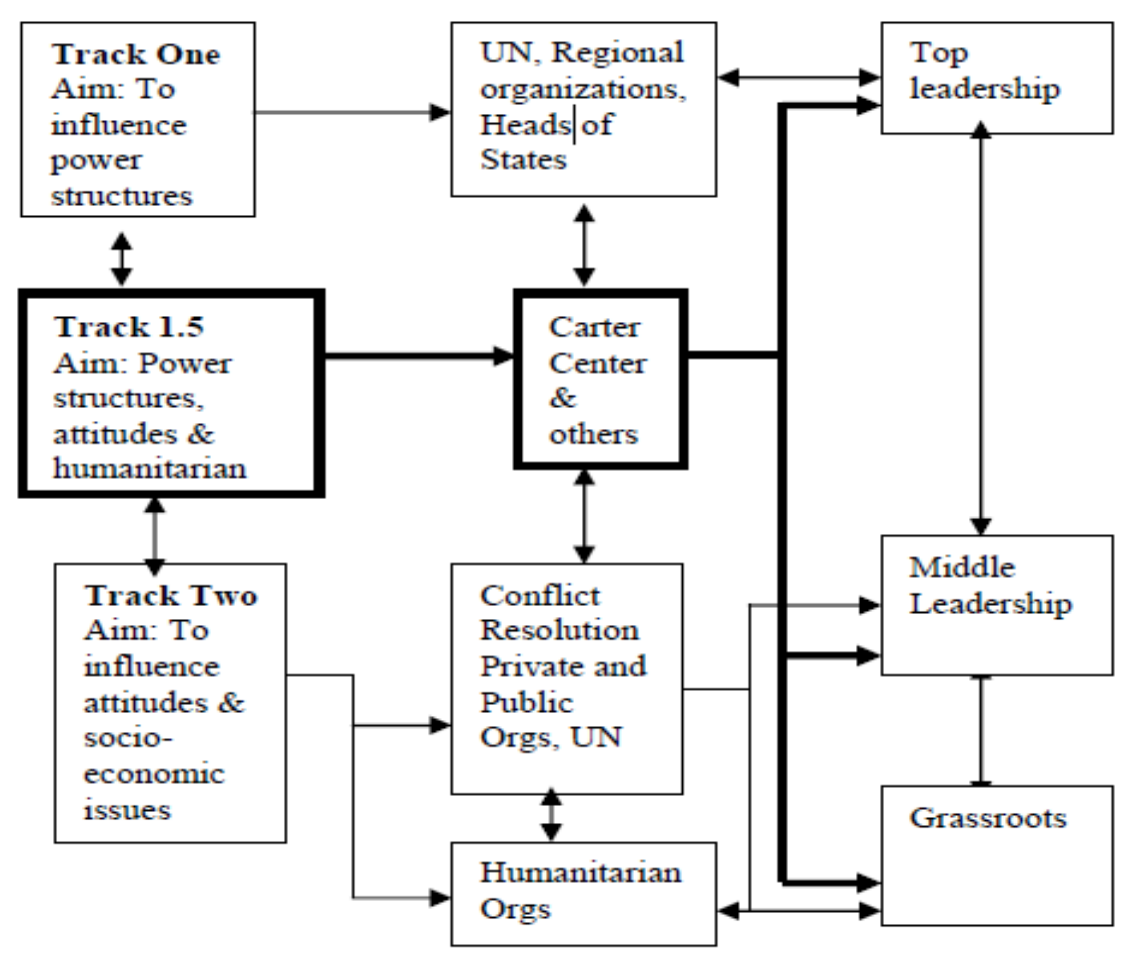

Figure 2 - Schema of Second Track Diplomacy Phase

Second track diplomacy is not designed to replace diplomacy on the one or official line, but this type of diplomacy often opens the way for formal negotiations by initiating attitude changes in public opinion and decision-makers. There are three stages of the second track diplomacy activity:

a. The first is a series of workshops or forums on problem-solving. These workshops are designed to bring influential people from both conflicting groups, but not the main decision-makers, together to look for alternative ways to limit the conflict.

b. Influence public opinion and change the attitudes and perceptions of support groups (protagonists). These changes in attitude and perception depend on the changes made by the participants in the problem-solving workshop.

c. Transformation process. Mass communication will be an important element in this process. Besides mass media, academic journals, conferences, and special events can help change perceptions.

Regional Comprehensive Economic Partnership (RCEP). The importance of cooperation between countries in the economic field between conflicting countries will be able to provide a part of the solution to the LCS dispute. This is based on the reality that the root cause of the conflict is the economy in fighting over natural resources. The history of the formation of a regional comprehensive economic partnership (RCEP) as a manifestation of ASEAN's response to economic dynamics in the region and globally in the form of integration of ASEAN countries with the global economy. The RCEP has a progressive goal of eliminating tariffs and non-tariff barriers and facilitating and increasing transparency among member countries. There are two important points for Asean related to Rcep activities, First, the direction of ASEAN economic and trade cooperation orientation is needed to compromise the risk of regionalism / mega regionalism sovereignty which is expected to be able to contribute to defusing tensions with China or the US. Second, the future of the pillars of the ASEAN Economic Community is determined by the perception and public support in the country for a variety of bilateral and multilateral free trade agreements and formats. Thus the existence of RCEP is expected to be able to provide solutions for LCS disputes. 


\section{CONCLUSION}

STRAD is a form of resolving non-governmental, informal, and informal conflicts that has the potential to reduce the tendency of prolonged conflict by increasing dialogue and promoting shared interests among warring groups. The importance of pursuing informal communication between conflicting groups is that they can reduce the intensity of conflict before formal talks are held. These informal interventions are easier to implement to deal with intra-state conflicts.

Indeed, STRAD should not replace first-track diplomacy, but rather as an additional channel that offers a preliminary segment to carry out dialogue productively. As a predialogue tool, STRAD's efforts can provide important information to pave the way for peaceful conflict resolution. In general, STRAD diplomacy can be most effective when it is linked to the formal peace process at the government level. Although STRAD is a relatively new practice, it has been able to produce some success in diplomacy between countries. Based on the research results, using the STRAD concept can increase the value of Regional Comprehensive Economic Partnerships (RCEP) for Indonesia in this region with optimal, effective and efficient conditions.

\section{ACKNOWLEDGEMENTS}

The authors greatly acknowledge the support from University of Brawijaya, Malang, Indonesia for providing the necessary resources to carry out this research work. The authors are also grateful to the anonymous reviewers and editorial board for their many insightful comments, which have significantly improved this article.

\section{REFERENCES}

1. Ames, Roger T. 1993. SunTzu, The Art of Warfare; the First English Translation Incorporating the Recently Discovered Yin-Chueh-Shan Texts, Ballantine Books.

2. Aplianta, Derry, Ministry of Foreign Affairs, Indonesia. 2017. Indonesia's Response in the South China Sea Disputes: A comparative analysis of the Soeharto and the postSoeharto era. Journal of ASEAN Studies.

3. Buszynski, Leszek. 2010. Rising Tensions in the South China Sea: Prospects for a Resolution of the Issue. Security Challenges, Vol. 6, No. 2 (Winter 2010), pp. 85-104.

4. Bungin, Burhan H.M. 2007.Penelitian Kualitatif : Komunikasi, Ekonomi, Kebijakan Publik, dan Ilmu social, Jakarta : Kencana Prenama Media Group.

5. Creswell, John W. 2004. Research Design: Qualitative and Quantitative Approach. California: Sage.

6. Digvijaysinh, Thakore. 2013. Conflict and Conflict Management. IOSR Journal of Business and Management (IOSR-JBM), e-ISSN: 2278-487X.Volume 8, Issue 6 (Mar. Apr. 2013), PP 07-16.

7. Fukunaga, Yoshifumi. 2014. ASEAN's Leadership in the Regional Comprehensive Economic Partnership. Asia and the Pacific Policy Studies. Wiley Publishing Asia Pty Ltd and Crawford.

8. Ikeshima, Taisaku. 2013. China's Dashed Line in the South China Sea: Legal Limits and Future Prospects. Waseda Global Forum No. 10, Pp. 17-50.

9. John Conyers, 1991, Military Sealift Command Contract for Operation Desert Shield, Report to the Chairman Committee on Government operation, House of Representative.

10. Kim, Jiye. 2016. China's Diplomacy towards the South China Sea Disputes. JNU, ISA-HK 2016, Page 1 of 20.

11. Kraft; John Davies; and Edy Kaufman. 2000. Second Track/Citizens" Diplomacy: An Overview, Second Track / Citizens' Diplomacy: Concepts and Techniques for Conflict Transformation, eds. John Davies and Edy Kaufman, Oxford, Rowman \& Littlefield Publishers. 
12. Mapendere, Jeffrey. 2016. Track One and a Half Diplomacy and the Complementarity of Tracks COPOJ - Culture of Peace Online Journal, 2(1), 66- 81. ISSN 1715-538X

13. Montville, J. 1991. Track Two Diplomacy: The Arrow and the Olive Branch: A case for Track Two Diplomacy. In, V. D. Volkan M.D., J. Montville, \& D. A. Julius (Eds.), The Psychodynamics of International Relations: Vol. 2. Unofficial diplomacy at work (pp.161175). Massachusetts: Lexington Books.

14. Robinson, C. 2010. When conflict happens: navigating difficult interactions in senior teams - fostering a culture of constructive engagement. Business Strategy Series, 11(4), p. $214-218$.

15. Rustandi, Agus, Captain. 2015. The Impact of China's 'Nine-Dash Line' Claim on ASEAN's Role in the Indo-Pacific Region. Indo-Pacific Strategic Papers, August 2015.

16. Scarlett, Matthew. 2009. Coercive Naval Diplomacy, Naval War College, Newport.

17. Schellenberg, James A. 1996. Conflict Resolution: Theory, Research, and Practice. New York: State University of New York Press. 